\title{
FACTORS AFFECTING THE CAPACITY AND THE INTERDEPENDENCE OF PROGRESSIVE FARMERS IN WEST JAVA INDONESIA
}

\author{
Faktor yang Berpengaruh terhadap Kapasitas dan Kemandirian Penyuluh Swadaya \\ di Jawa Barat
}

\author{
Yoyon Haryanto ${ }^{1, *}$, Sumardjo ${ }^{2)}$, Siti Amanah ${ }^{2)}$, Prabowo Tjitropranoto ${ }^{2)}$
}

\author{
${ }^{1}$ Bogor Agricultural Extension High School, Agency of PPSDMP - Ministry of Agriculture \\ ${ }^{2}$ Department of Communication Science and Community Development, Faculty of Human Ecology, IPB University, Bogor 16680, \\ Indonesia \\ ${ }^{*}$ E-mail: yoyonharyanto@gmail.com
}

\begin{abstract}
The limited number of government extension agents (PNS/THL-TBPP) is urging progressive farmers to play a role in extension activities. This study aimed to analyze the capacity and interdependence levels of progressive farmers as well as factors affecting capacity and interdependence. This study used survey design with cluster random sampling technique consisting of 224 respondents who represent progressive farmers in four districts (Bogor, Karawang, Majalengka, and Sukabumi) of West Java. Data were collected through questionnaires and in-depth interviews. Data processing used descriptive and path analysis techniques. The results showed that progressive farmers have good capacity in empowering farmers. Progressive farmers also have a high category of interdependence. This indicates that progressive farmers have the initiative and the willingness to realize their expectations (competitiveness), are able to cooperate with others in partnership, and have a high filter system in determining best decisions for farmers' empowerment activities. Factors that positively affect the interdependence of progressive farmers are the capacity of progressive farmers, and followed respectively by community social capital, age, access to information technology, access to conventional information sources, and formal education level.
\end{abstract}

Keywords: Capacity, Interdependence, Progressive Farmers, Social Capital

\section{ABSTRAK}

Rendahnya kapasitas penyuluh swadaya menyebabkan fungsinya dalam memberdayakan petani cenderung tergantung penyuluh pemerintah (PNS/THL-TBPP), dan sebagian besar organisasi yang di bina oleh penyuluh swadaya berbasis bantuan pemerintah yang keberlanjutannya selalu tergantung terhadap jangka waktu pelaksanaan program. Penelitian ini bertujuan untuk menganalisis tingkat kapasitas dan kemandirian penyuluh swadaya serta faktor yang berpengaruh terhadap kapasitas dan kemandiriannya. Penelitian ini menggunakan desain survei dengan teknik pengambilan sampel cluster random sampling, diperoleh 224 responden yang mewakili penyuluh swadaya di empat kabupaten (Bogor, Karawang, Majalengka dan Sukabumi) di Jawa Barat. Data dikumpulkan melalui kuesioner dan wawancara mendalam. Pengolahan data menggunakan teknik deskriptif dan path analysis. Hasil penelitian menunjukkan penyuluh swadaya memiliki tingkat kapasitas yang baik dalam pemberdayaan petani. Penyuluh swadaya juga memiliki tingkat kemandirian dalam kategori tinggi. Hal ini menunjukkan bahwa penyuluh swadaya memiliki inisiatif dan kemauan keras untuk mewujudkan harapannya (daya saing), mampu bekerja sama dengan pihak lain dalam kedudukan yang setara (daya sanding), dan mempunyai daya saring yang tinggi dalam menetapkan pilihan tindakan terbaik bagi kegiatan pemberdayaan petani. Faktor yang memiliki pengaruh positif terhadap kemandirian penyuluh swadaya adalah modal sosial masyarakat yang memberikan kontribusi tinggi, dan diikuti secara berurutan oleh factor usia, akses terhadap teknologi informasi, akses sumber informasi konvensional, dan tingkat pendidikan formal yang di dukung oleh adanya peningkatan kapasitas individu penyuluh swadaya.

Kata kunci: Kapasitas, Kemandirian, Penyuluh Swadaya, Modal Sosial

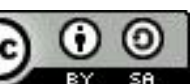

Content from this work may be used under the terms of theCreative Commons Atribusi-BerbagiSerupa

4.0 International. Any further distributionof this work must maintain attribution to the author(s) and the title of the work, journal citation and DOI.

Published under Department of Communication and Community Development Science, IPB University ISSN : 1858-2664 | E-ISSN : 2442-4110 



\section{INTRODUCTION}

The limited number of government extension agents (PNS / THL-TBPP) in conducting extension activities causes a gap of intensity in rural areas, thus requiring the role of advanced farmers as an alternative solutionto carry out farmer to farmer extension. These advanced farmers subsequently served as progressive farmers. This is due to extension activities are organized by fellow farmers, who have the potential to disseminate innovation in a cost-effective and generally sustainable ways beyond project life (Lukuyu et al. 2012).Progressive farmers are an integral part of the farm community so that they have a high sense of empathy, especially to help others. Progressive farmersalso have the potential to become farmers'supervisor who are better in understanding the needs of farmers in accordance with their conditions, both in choosing innovation and information related to farming and at the same time become the agents of change that live with farmers.Considering the access to government extension services is diminishing due to the declining number of government extension agents, while farmers still need a figure that is capable of facilitatinginnovation and organizing farmers' institutions, particularly individuals who are very familiar with their condition. Therefore, progressive farmersmay be an alternative solution that can answer such problem by maximizingtheir ability to help farmers to understand and meet their own needs.

This is in accordance with Sumardjo (1999) who states that the extension agents should also be able to awaken the farmers to their real needs. Therefore, ideally, progressive farmers are expected to increase their capacity in order to increase their interdependence, both in competitiveness, filter systems, and partnerships so that the effectiveness of farmer to farmer extension can be realized.This is confirmed by Verhagen (1996) that one way to achieve interdependent farmers is by performing an empowerment. Progressive farmers are part of the empowerment that comes from the community so that they understand the conditions experienced by farmers. It is also confirmed by Selener and Chenier (1997)and Lukuyuet al.(2012) who state that progressive farmers are individuals with low or no formal education but have the ability to improve themselves to become good examples of other farmers.

However, in field, not all the progressive farmers have the same capacity in promoting and organizing the group as well as supervising farmers due to differences in capacity of each individual. This lack of capacity causes progressive farmers are not able to provide good learning to the farmers Jatnika (2016) and are only seen as government extension assistants in conveying information to the community (Riana et al. 2015). Therefore, the capacity of progressive farmers needs to be improved, thusfarmer to farmer extensioncan be more optimum as stated by Jatnika (2016).Increased capacity and interdependenceof progressive farmersare expected to contribute on the effectiveness offarmer to farmer extension and may accelerate the process of achieving the welfare of farmers. This also support the results of previous research, which was increasing the capacity and independence of farmers to strengthen extension conducted by farmer to farmer extension approach, in which farmers become a center of activity in the development and dissemination of technology, both research technology and traditional technology, and involving farmers in sharing efforts to increase knowledge and skills with fellow farmers(Haryanto \& Yuniarti, 2017).The purpose of this study was to analyze the levels of capacity and interdependence of progressive farmers and factors that affect the capacity and interdependence.

\section{METHODS}

The population in this study was progressive farmers based on data Pusluhtan-Ministry of Agriculture (2017) in which it is recorded that a total of 1.855 progressive farmers spread across 22 districts and cities in West Java Province. The sampling technique used in this study was cluster random sampling. The first stage of this study was conducted byselecting four districts (Karawang, Majalengka, Sukabumi, and Bogor) based on the results obtained by Sumardjo (1999) that divided West Java into four zones (North, Central, South and Jabotabek). The four districts have a population of 482 progressive farmers. Due to the large number of individuals in the population, the second stage of this study was conducted by determining the sample of progressive farmers in 
the four districts using the Sloviring formula in which it was obtained 224 samples. Meanwhile in the third stage, after sample size was proportionally determined, sample collection was carried out by considering progressive farmers'criteria that came from the advanced and the lesson developed groups proportionally.

Variables in this study consisted of the characteristics of progressive farmers (X1) including age, formal education, non-formal education, access to information technology. The social capital of community (X2) consists of trust, values, and network. Meanwhile, variable Y1 is the level of capacity owned by progressive farmers including the ability to assist the farmers' technique, training ability and giving the example of farmers, disseminating innovation and information, maintaining local wisdom as well as having a figure as an informal leader. Interdependence level of progressive farmers is transformed to variable Y2 with sub-variables of competitiveness, filter system, and partnership. Hypothesis of this study is that the characteristics of progressive extension agents and social capital have a real direct influence in increasing the capacity and independence of self-help instructors.

Primary data were collected directly from the main source, namely progressive farmersas research samples with interview techniques using questionnaires and field observation, and indepth interviews to farmers who supervised by progressive farmers to confirm the results obtained. Secondary data obtained by recording data that are already available in agencies related to the topic of research. Validityand reliability tests of the instrument were carried out to 30 progressive farmers of Cianjur District. The pre-test results showed that the questionnaire is feasible to be used with validity value of $0.349-0.703$ and reliability value of 0.881 . Data analysis used descriptiveand path analysis with SPSS 20. Before data processed using path analysis, the data are transformed from ordinal to interval (Sumardjo, 1999).

\section{RESULT AND DISCUSSION}

\section{Characteristic of Progressive Farmers}

In general, progressive farmers have an age range in Middle-Aged Adults (30-50 years), which indicate that they are in productive condition to work and look for opportunities or lucrative information related to improving welfare and self-prestige. The average formal education of progressive farmers is in the range from Senior High School to Diploma, however, their non-formal education activities (self-development training) remain very low. The low number of those nonformal activities is due to the lack of opportunities available from educational institutions and government training in providing and developing the capacity of progressive farmers. For more details, the characteristics of progressive farmers are presented in Table 1. 
Table 1 Characteristics of progressive farmers in four districts in West Java of 2017

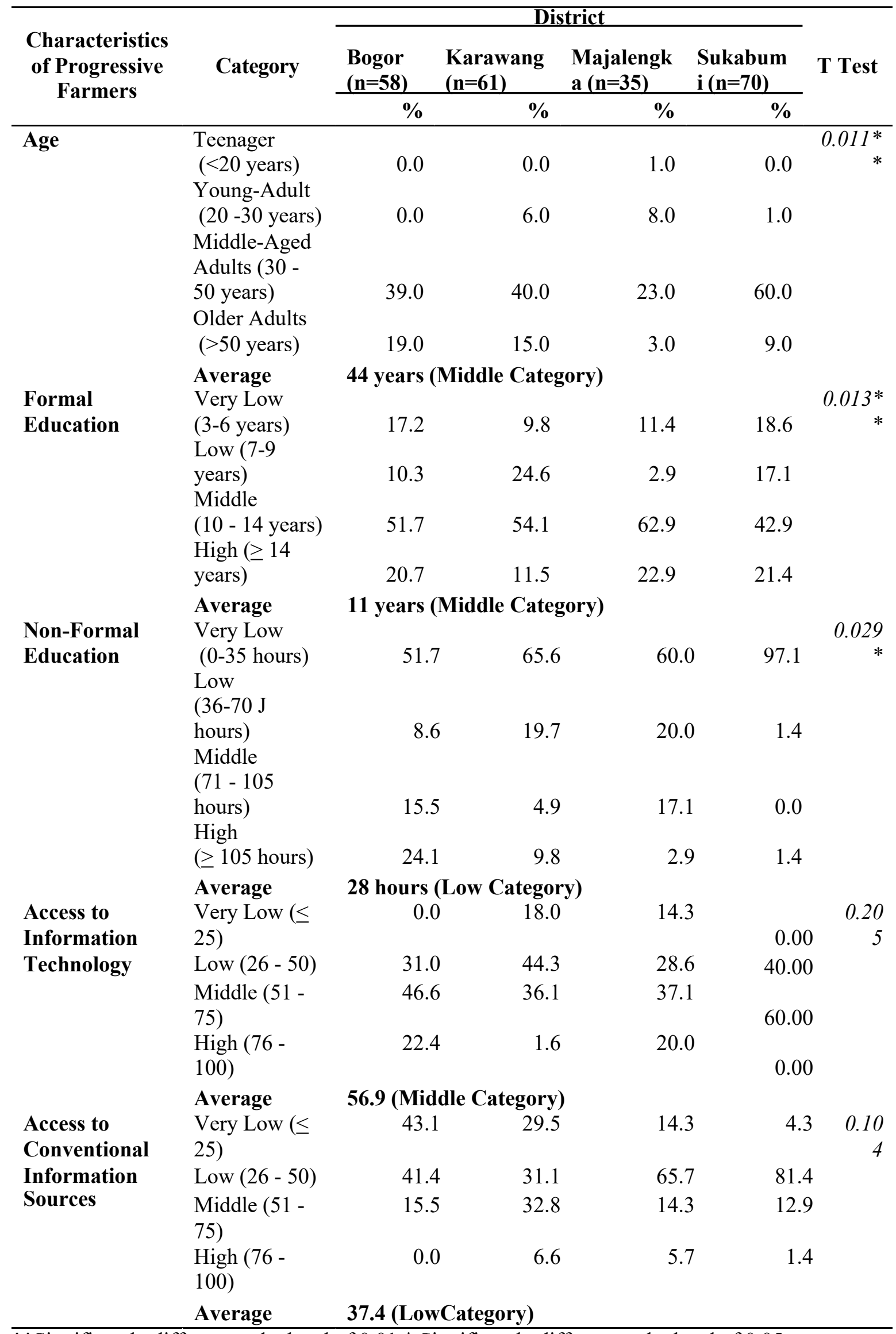

$* *$ Significantly different at the level of $0.01, *$ Significantly different at the level of 0.05 
The result above is consistent with Lodismith and Robert (2010) that age reflects the experiences farmers experienced success in life with a measure of competence, happiness, a healthy soul, and work. Therefore, a suitable age for supervising and nurturing farmers is in the middle-aged adults range. Education has an influence on the ability of a person in running a job (Subagio 2008; Fatchiya 2010; Yunita 2011), which means that education is something related to someone to think and act in accordance with the self-capacity. Moreover, research conducted by Alonge et al. (2014) revealed that education relates to the interdependence of the individual. Therefore, progressive extension agents are very helpful in providing motivation to the young generation of farmers. This is in line with the results of Oeng and Haryanto (2018) research, which states that progressive extension agents can provide motivation and become attraction to young generation interested to work in the agricultural sector.

Progressive farmers have access to a good information technology to facilitate them in finding the latest innovations which are appropriate for the farmer's need, however, they are still weak in access to conventional information sources such as newspapers, agricultural magazines and others (Table 1). This is quite natural sinceprogressive farmers are relatively more open to information technology in which it is easier to access the latest sources of innovation and information compared to reading conventional newspapers or magazines.The difficulty of accessing information sources limits farmers' knowledge about the various useful information and causes low adoption rates (Aker 2011, Lapple et al.2013; Omorede 2014), however, it can be solved by the presence of progressive farmers. The progressive farmers are able to access technology information sources so they can obtain the latest information and innovations as well as choose the appropriate choices for farmers' needs. The presence of progressive farmers in the middle of the community is able to make a difference to the farmers, particularly in obtaining the information needed.

This confirms the research of Oktavia et al. (2017) that farmers have a tendency to look for and disseminates information through interpersonal channels, particularly for progressive farmers. Therefore, progressive farmers have the potential to be an alternative solution to solving problems resulted from the lack of extension agents currently. The characteristics of progressive farmer in each district differ in age, levels of formal and non-formal education but relatively similar in access to information technology (Table 1). The distribution of age of progressive farmers in four districts is mostly in the middle-aged adults, although there are someprogressive farmersat the young adult and teenagers.

Majalengka district is the only district that has progressive farmers with the young agecategory. These young progressive farmers are one reflection of the young generation's interest in the agricultural sector. They have a strong motivation to expand their business so that they may become modelsfor other farmers and are expected to assist their community in solving problems that have been unreachable by government extension agents. Thisis reinforced byKiptot and Franzel (2014) that one of the characteristics of progressive farmers is the existence of strong altruism and motivation.

The presence of progressive farmersmay also assist farmers in obtaining access to information quickly as it suits the needs of farmers. This is due to progressive farmershave more ability in accessing information technology compared to other farmers. The presence of advanced technology and information helpsprogressive farmersto choose a variety of information sources needed both from electronic media, newspaper and internet.

Before being legalized as progressive farmers, farmers have long been involved in agricultural extension activities. Period of Bimas to Supra Insus is known as "Farm Contact", thatis advanced and communicative farmers which selected as a connection between extension agentsand farmers. Due tothe difficulty to reach all farmers at once, hence it needs the help of farmers as communicators Syahyuti (2016). In addition to be progressive farmers' assistant, farmers also play an active role in the concept of farmer to farmer learning. Conceptually, this approach is believed to be more effective.Progressive farmersact as a reaction to unbalanced role of top down by government extension agents so as reducing farmers' participation and initiative (Kiptot \& Franzel, 
2014). Extension farmers are individuals with low or no formal education but have the ability to improve their capacity so they are able become farmers'supervisor (Seleneret al.1997; Lukuyu 2012). Progressive farmers are identified as head of farmer groups (Indraningsihet al. 2010; Riana et al. 2015). This is because the head of the farmer group generally has a higher education, higher social status than the members, and better farming (Indraningsihet al., 2010). In addition, the head of farmer group also has a strong attitude and social capital (Kiptot \& Franzel, 2014).

\section{Social Capital of Community}

Progressive farmers have a high social capital of the community (Table 2). The trust of the farmers to all progressive farmers is a proof that progressive farmers are those who can bridge the needs of the farmers and the stakeholders involved in the farming process. Intensive interaction with farmers may also facilitateprogressive farmersin applying suitable innovations with the values of local wisdomalready existed.This is in line with the concept of social capital development in extension activitiesincluding aspects of relationships between individuals that allow them to create values of local wisdom (Sumardjo 2010). Based on observations, the presence of progressive farmers is able to revive local wisdom that had previously been eroded by agricultural modernization, as an example, in terms of predicting simultaneous planting period and traditional irrigation methods considered to be quite effective in regulating the distribution of water to each farmland.

Ease of accesstogovernment extension agents, research institutes, private extension agents and other stakeholders, allow progressive farmers to have a good network so that these values can be beneficial to farmers in the community. Therefore, progressive farmers can be regarded as potential assets of human resources owned in rural areathat is capable of moving farmers out of their current marginal condition.Social capital is an asset generated when people interact and build a trust relationship that benefits the group (Gotschiet al. 2008; Sobel 2002). This means that the belief of the farmers in their communitiesis the main key in determining social capital in rural areas. The results are in harmony with Pranadji (2006) that the trust aspect becomes the main component of social capital forming in rural areas, other aspects, such as cooperation and networking, will not be established steadily if it is not based on mutual trust among community members.Progressive farmers in term of social capital are positioned as catalysts that can accelerate the process of change in farmers' behavior because they have advantages not shared by other types of extension agents. Syahyuti (2016) also states that the progressive farmers strengthen the relationship between humans. In other words, the progressive farmer is not just a worker, but also play a role as a social being that has energy in his community characterized by his creativity that can not be defeated by other beings on this earth.

Progressive farmers in the four districts are a reflection of modern farmers today, yet are able to maintain the spirit or social spirit of the village community which is the binding force of their collective life. This is seen by the absence of social capital differences between progressive farmers in the four districts (Table 2). The high social capital of the community to progressive farmers is also due to most of the progressive farmers is a community leader (head of the farmer group, entrepreneur of agricultural product). This makes it easy for the farmers to believe in progressive farmers because they have shown their ability to maintain the local values in the rural areas and built good relationships with stakeholders for farmers' progress. These results are consistent with Kiptot and Franzel (2014) that social capital is a trusting relationship in which group members use trust as a means of ensuring that progressive farmers fulfill their obligations.

The presence of strong local figures may avoid manipulative participation towards democratic independent participation (Arnstein 1969). In this context, progressive farmers may become such figures. This is the unique position for progressive farmers because they are part of the farming community itself. In line with the participation of progressive farmers, the concept of empowerment is highly visible with political nuance, because it relates to power. Progressive farmers as part of the community should also be able to build access and political capital. In addition to participatory and political capital, progressive farmers also have more value in the ownership of social capital. 
Table 2. Social capital of community in the four districts in West Java of 2017

\begin{tabular}{|c|c|c|c|c|c|c|}
\hline \multirow{3}{*}{$\begin{array}{c}\text { Social } \\
\text { Capital of } \\
\text { Community }\end{array}$} & \multirow{3}{*}{$\begin{array}{l}\text { Category } \\
\text { (Score) }\end{array}$} & \multicolumn{3}{|c|}{ District } & \multirow[b]{2}{*}{$\begin{array}{c}\text { Sukabumi } \\
(\underline{n}=70)\end{array}$} & \multirow{3}{*}{ T Test } \\
\hline & & $\begin{array}{l}\text { Bogor } \\
(n=58)\end{array}$ & $\begin{array}{c}\text { Karawan } \\
g(n=61)\end{array}$ & $\begin{array}{l}\text { Majalengka } \\
(\mathrm{n}=35)\end{array}$ & & \\
\hline & & $\%$ & $\%$ & $\%$ & $\%$ & \\
\hline \multirow[t]{5}{*}{ Trust } & Very Low $(\leq 25)$ & 0.0 & 0.0 & 0.0 & 0.0 & \multirow[t]{5}{*}{0.281} \\
\hline & Low $(26-50)$ & 5.2 & 1.6 & 2.9 & 1.4 & \\
\hline & Middle (51 - 75) & 12.1 & 31.1 & 5.7 & 8.6 & \\
\hline & High $(76-100)$ & 82.8 & 67.2 & 91.4 & 90.0 & \\
\hline & Average & $86.1(\mathrm{Hi}$ & gh Category) & & & \\
\hline \multirow[t]{5}{*}{ Values } & Very Low $(\leq 25)$ & 3.4 & 0.0 & 2.9 & 1.4 & \multirow[t]{4}{*}{0.452} \\
\hline & Low $(26-50)$ & 1.7 & 1.6 & 0.0 & 0.0 & \\
\hline & Middle (51 - 75) & 5.2 & 13.1 & 0.0 & 2.9 & \\
\hline & High $(76-100)$ & 89.7 & 85.2 & 97.1 & 95.7 & \\
\hline & Average & 92.8. (H & gh Category) & & & \\
\hline \multirow[t]{5}{*}{ Networking } & Very Low $(\leq 25)$ & 0.0 & 0.0 & 0.0 & 0.0 & \multirow[t]{5}{*}{0.338} \\
\hline & Low $(26-50)$ & 6.9 & 0.0 & 2.9 & 1.4 & \\
\hline & Middle (51 - 75) & 3.4 & 16.4 & 2.9 & 18.6 & \\
\hline & High (76 - 100) & 89.7 & 83.6 & 94.3 & 80.0 & \\
\hline & Average & \multicolumn{4}{|c|}{90.7 (High Category) } & \\
\hline
\end{tabular}

**Significantly different at the level of $0.01, *$ Significantly different at the level of 0.05

\section{Capacity of Progressive Farmers}

Overall, capacity of progressive farmers in empowering farmers is in the middle/good categories (Table 3). This provides an illustration that progressive farmers have been able to contribute well to extension activities so as farmers run their business better. This condition is consistent with Brown and Westaway (2011)that as individuals, progressive farmers have the ability to grow and develop according to their capacity, so as to be able to mobilize extension functions from farmers to farmers. This result also confirms that the capabilities possessed by progressive farmers are relatively similar in terms of technical assistance that disseminate innovations which are appropriate to the needs of farmers, provides training to farmers, becomes informal leaders, and maintains local wisdom. This is incontrast with Indraningsihet al. (2013) who reveal that progressive farmers have a high determination on their ability as technical assistants, whereas Lukuyu (2012) states that it is on the ability to train partners and organizes the organization as informal leaders.

The uniformity of capacity of progressive farmers is based on several things, namely the proximity of progressive farmers to the government extensionists in order to obtain information about extension activities, the proximity of progressive farmers to the researchers in order to obtain the latest innovations to access other sources of information. Nevertheless, the attention of the government, particularly education and training institutions, is still low in empowering the capacity of progressive farmers. This is seen from practicing time (Table 1) which is still in a very low category. Therefore, the existing capacity is still possible to be improved again if there is optimum support from the related institutions so that the progressive farmers have a better capacity to empower farmers. 
Table 3. Distribution of the capacity of progressive farmers in the four districts of West Java Province in 2017

\begin{tabular}{|c|c|c|c|c|c|c|}
\hline \multirow{3}{*}{$\begin{array}{c}\text { Capacity of } \\
\text { Progressive } \\
\text { Farmers }\end{array}$} & \multirow{3}{*}{$\begin{array}{l}\text { Category } \\
\text { (Score) }\end{array}$} & \multicolumn{4}{|c|}{ District } & \multirow{3}{*}{$\begin{array}{c}T \\
T e s t\end{array}$} \\
\hline & & $\begin{array}{l}\text { Bogor } \\
(\mathrm{n}=58)\end{array}$ & $\begin{array}{c}\text { Karawang } \\
(\underline{n}=61)\end{array}$ & $\begin{array}{c}\text { Majalengk } \\
\underline{\mathbf{a}(\mathrm{n}=35)}\end{array}$ & $\begin{array}{c}\text { Sukabu } \\
\text { mi } \\
(\mathrm{n}=70)\end{array}$ & \\
\hline & & $\%$ & $\%$ & $\%$ & $\%$ & \\
\hline \multirow[t]{5}{*}{ Technical Ability } & $\begin{array}{l}\text { Very Low }(\leq \\
25)\end{array}$ & 1.7 & 4.3 & 3.3 & 2.9 & \multirow[t]{5}{*}{$\begin{array}{r}0.07 \\
6\end{array}$} \\
\hline & Low $(26-50)$ & 8.6 & 2.9 & 18.0 & 22.9 & \\
\hline & $\begin{array}{l}\text { Middle (51 - } \\
75)\end{array}$ & 41.4 & 81.4 & 54.1 & 71.4 & \\
\hline & High $(76-100)$ & 48.3 & 11.4 & 24.6 & 2.9 & \\
\hline & Average & \multicolumn{4}{|c|}{66.5 (Middle Category) } & \\
\hline \multirow[t]{5}{*}{$\begin{array}{l}\text { DisseminatingAb } \\
\text { ility }\end{array}$} & $\begin{array}{l}\text { Very Low }(\leq \\
25)\end{array}$ & 1.7 & 4.9 & 11.4 & 4.3 & \multirow[t]{5}{*}{$\begin{array}{r}0.12 \\
4\end{array}$} \\
\hline & Low $(26-50)$ & 6.9 & 13.1 & 28.6 & 12.9 & \\
\hline & $\begin{array}{l}\text { Middle (51 - } \\
75)\end{array}$ & 50.0 & 70.5 & 54.3 & 68.6 & \\
\hline & $\operatorname{High}(76-100)$ & 41.4 & 11.5 & 5.7 & 14.3 & \\
\hline & Average & $\begin{array}{l}65.8 \\
\text { (MiddleC }\end{array}$ & Itegory) & & & \\
\hline \multirow[t]{5}{*}{ Training Ability } & $\begin{array}{l}\text { Very Low }(\leq \\
25)\end{array}$ & 5.2 & 6.6 & 14.3 & 4.3 & \multirow[t]{5}{*}{$\begin{array}{r}0.03 \\
0^{*}\end{array}$} \\
\hline & Low $(26-50)$ & 12.1 & 26.2 & 17.1 & 4.3 & \\
\hline & $\begin{array}{l}\text { Middle (51 - } \\
75)\end{array}$ & 34.5 & 49.2 & 57.1 & 74.3 & \\
\hline & High $(76-100)$ & 48.3 & 18.0 & 11.4 & 17.1 & \\
\hline & Average & \multicolumn{4}{|c|}{56.1 (Middle Category) } & \\
\hline \multirow[t]{5}{*}{$\begin{array}{l}\text { Informal } \\
\text { Leadership }\end{array}$} & $\begin{array}{r}\text { Very Low }(\leq \\
25)\end{array}$ & 5.2 & 4.9 & 17.1 & 4.3 & \multirow[t]{4}{*}{$\begin{array}{r}0.10 \\
1\end{array}$} \\
\hline & Low $(26-50)$ & 10.3 & 18.0 & 14.3 & 1.4 & \\
\hline & $\begin{array}{l}\text { Middle (51 - } \\
75)\end{array}$ & 36.2 & 55.7 & 51.4 & 58.6 & \\
\hline & High $(76-100)$ & 48.3 & 21.3 & 17.1 & 35.7 & \\
\hline & Average & 69.3 (Mid & lle Category) & & & \\
\hline \multirow[t]{5}{*}{ Local Wisdom } & Very Low $(\leq \leq$ & 1.7 & 3.3 & 8.6 & 2.9 & \multirow{5}{*}{$\begin{array}{r}0.33 \\
9\end{array}$} \\
\hline & Low $(26-50)$ & 5.2 & 13.1 & 2.9 & 1.4 & \\
\hline & $\begin{array}{l}\text { Middle(51 - } \\
75)\end{array}$ & 3.4 & 9.8 & 8.6 & 2.9 & \\
\hline & High $(76-100)$ & 89.7 & 73.8 & 80.0 & 92.9 & \\
\hline & Average & \multicolumn{4}{|c|}{69.4 (Middle Category) } & \\
\hline
\end{tabular}

$* *$ Significantly different at the level of $0.01, *$ Significantly different at the level of 0.05

Theresults of $\mathrm{T}$ test indicate that capacity of progressive farmers in the four districts is not strongly different(Table 3). The training ability of progressive farmers in Bogor and Sukabumi are better than those of the other two districts. This is because they are often involved in extension and research activities organized by the government, so they have a variety of innovations and 
information directly obtained from themain sources that make it easy to relay to farmers in their communities. This is confirmed by interviews with progressive farmers and common farmers at the research sites, where they are often involved in various technological testing activities carried out by government and research institutes as well as private institutes. Such involvement has a positive impact on both progressive farmers and common farmers in which they may learn from each other and are able to choose innovations that meet their needs. It is also known that the role of progressive farmers has existed since the era of farmers' guide which then changed to extension agents, and now recognized by the government with the term of progressive farmers. Progressive farmers have been able to provide problem-solving among farmers and develop local technology for their farming.This condition confirms the results obtained by Shrestha (2014) that the involvement of progressive farmers in research activities has been able to produce local technology and has been proven effective in disseminating these innovations to farmers. The innovations generated by progressive farmers also have a tendency to be followed by other farmers (Lukuyu 2012; Kiptot \& Franzel 2014), because the information provided by progressive farmers is easier accepted by other farmers (Shelton, Wilke, Franti, \& Josiah, 2009)

In general, the capacity of progressive farmers should be improved, particularly on the interdependence aspect. The results of Indraningsih et al. (2016) provide information that the ability of progressive farmers is relatively diverse, however, the mastery of the technical aspects is adequate. During this time, progressive farmersare relatively limited in developing their capacity, consequently, farmers who livewith those progressive farmershave not felt theircontribution. The limited capacity of progressive farmers provides a diverse perception for farmers, especially related to the role and performance. One of the perceptions that appear in the community about progressive farmers is the same role between progressive farmers and farm contact or community leaders, so they have not significantly change the farmers' behavior in order to increase farmers' welfare.

Based on the above results, it indicates that progressive farmers are present because of the demands of participatory approaches so that farmers may become subjects in the agricultural development program, started from the stage of problem identification, planning, implementation until evaluation. Progressive farmers have an advantage in performing their role as agents of change in rural areas as part of their community and more trusted by farmers. In order to achieve this point, efforts can be done are enhancing the capacity of progressive farmers in organizing and establishing the interdependence of progressive farmers so that a participatory extension paradigm and removal of the government's old pattern (top-down) can be realized.

\section{Interdependence of Progressive Farmers}

Interdependence of progressive farmers is in the high category (Table 4). This indicates that the progressive farmers always develop and improve themselves and their lives, and have the initiative and the willingness to fulfill their expectation (competitiveness). Furthermore, they have been able to cooperate with others in an equal position (partnership) so that interdependence in mutual benefit situation in sustainable business partnership and filter system in determining the best action for running the business can be realized.

Progressive farmers are generally farmers, however, the level of interdependencethey have is different from other farmers in the community.This is due to the progressive farmersmostly havea higher level of education compared tothe farmers in general and more open to information technology that allows progressive farmers to beable in accessing the various information needed to build the image of themselves to be more creative and innovative without having to depend on the stakeholders in workingarea. This is confirmed by Abas (2016) that the higher the level of education of farmers, the more interdependent they are.Interdependence may occur due to the cooperation between farmers and farming organizations that work well (Burton, 2014; Emery, 2014; Emery \& Franks, 2012; Niska, Vesala, \& Vesala, 2012; Sutherland et al., 2012). Progressive farmer's currently have those criteria that be able to cooperate with common farmers and able to organizefarmers'organization, thus it becomes one of the causesofhigh category of progressive farmer'sinterdependence. 
Table 4. Distribution of interdependence levels of progressive farmers in the four districts of West Java Province in 2017

\begin{tabular}{|c|c|c|c|c|c|c|}
\hline \multirow{3}{*}{$\begin{array}{l}\text { Interdependence } \\
\text { Levels of } \\
\text { Progressive } \\
\text { Farmers }\end{array}$} & \multirow{3}{*}{$\begin{array}{c}\text { Category } \\
\text { (Score) }\end{array}$} & \multicolumn{3}{|c|}{ District } & \multirow{3}{*}{$\begin{array}{c}\text { Sukabumi } \\
(\mathrm{n}=70)\end{array}$} & \multirow{3}{*}{$\begin{array}{c}T \\
T e s t\end{array}$} \\
\hline & & $\begin{array}{l}\text { Bogor } \\
(n=58)\end{array}$ & $\begin{array}{c}\text { Karawang } \\
(\mathbf{n}=61)\end{array}$ & $\begin{array}{c}\text { Majalengka } \\
(\mathrm{n}=\mathbf{3 5})\end{array}$ & & \\
\hline & & $\%$ & $\%$ & $\%$ & & \\
\hline \multirow[t]{5}{*}{ Competitiveness } & Very Low $(\leq 25)$ & 3.4 & 1.6 & 0.0 & 0.0 & \multirow[t]{5}{*}{0.331} \\
\hline & Low $(26-50)$ & 5.2 & 11.5 & 8.6 & 2.9 & \\
\hline & Middle (51 - 75) & 8.6 & 24.6 & 20.0 & 24.3 & \\
\hline & High $(76-100)$ & 82.8 & 62.3 & 71.4 & 72.9 & \\
\hline & Average & \multicolumn{2}{|c|}{89.1 (High Category) } & & & \\
\hline \multirow[t]{5}{*}{ Filter System } & Very Low $(\leq 25)$ & 0.0 & 0.0 & 0.0 & 0.0 & \multirow[t]{4}{*}{0.241} \\
\hline & Low $(26-50)$ & 5.2 & 3.3 & 2.9 & 1.4 & \\
\hline & Middle (51 - 75) & 8.6 & 13.1 & 8.6 & 10.0 & \\
\hline & $\operatorname{High}(76-100)$ & 86.2 & 83.6 & 88.6 & 88.6 & \\
\hline & Average & \multicolumn{2}{|c|}{ 85.4 (High Category) } & & & \\
\hline \multirow[t]{5}{*}{ Partnership } & Very Low $(\leq 25)$ & 1.7 & 0.0 & 0.0 & 0.0 & \multirow[t]{5}{*}{0.343} \\
\hline & Low $(26-50)$ & 5.2 & 16.4 & 2.9 & 1.4 & \\
\hline & Middle (51 - 75) & 10.3 & 9.8 & 11.4 & 0.0 & \\
\hline & High $(76-100)$ & 82.8 & 73.8 & 85.7 & 98.6 & \\
\hline & Average & \multicolumn{2}{|c|}{92.3 (High Category) } & & & \\
\hline
\end{tabular}

$* *$ Significantly different at the level of $0.01, *$ Significantly different at the level of 0.05

The results of $\mathrm{T}$ test (Table 4) indicate that progressive farmers have similar levels of interdependence in the four districts.According to Sumardjoet al. (2014), it shows that progressive farmers in the four districts have interdependent social relationships with farmer partners in an equal position, thus there is no boss and staff relationships.Progressive farmers have competence shown in filter system, as an example, all information and innovation obtained by progressive farmers are adjusted first with the needs of farmers. In addition, progressive farmers should have the ability to partner with stakeholders in an equal and strategic position so as to play a role in organizing the farmer's organizations without having the dependence on one particular institution. This will be an advantage of progressive farmers to the figure that can encourage farmers' participation. This allows progressive farmers to play an active role, have control over the lives of their own communities, involved in community activities as well as development program (Syahyuti, 2016).

\section{Factors Affecting the Capacity of Progressive Farmers}

Factors that have a significant effect on capacity building of progressive farmers are age, formal education, access to information technology, access to conventional information sources and social capital (Table 5). The results showed that non-formal education including training, internships, field trips and seminars have no significant effect on the capacity building ofprogressive farmers. This indicates the presence of other factors that are quite dominant, thusthe effect is not detected. The results of field observation showed that non-formal education has not been experienced by all progressive farmers in the four districts of research sites, thus the contribution is very low in supporting the empowerment process undertaken by progressive farmers. They are more active in seeking information and innovation through access to information technology so that progressive farmers do not feel a lack of information and innovation even thoughdescriptively non-formal education is in a very low category. Therefore, progressive farmers have internalized their capacity in order to look for knowledge, attitudes, and skills needed to run farmer to farmer extension independently. This is confirmed by the results of Herman et al.(2008) 
that the capacity is an aspect internalized in someone indicated by the knowledge, attitude, and skills to carry out activities.

Table 5. Statistical analysis of factors affecting the capacity of progressive farmers

\begin{tabular}{lcr}
\hline \multicolumn{1}{c}{ Variable } & Value & p-value \\
\hline R square & 0.601 & \\
\hline Coefficientof Pathway $\mathrm{X}_{1}$ to $\mathrm{Y}_{1}$ & & \\
Age $\left(\mathrm{X}_{11}\right)$ & 0.249 & $0.000^{* *}$ \\
Formal Education $\left(\mathrm{X}_{12}\right)$ & 0.080 & $0.016^{* *}$ \\
Non-Formal Education $\left(\mathrm{X}_{13}\right)$ & 0.101 & 0.089 \\
Access to Information Technology $\left(\mathrm{X}_{14}\right)$ & 0.201 & $0.001^{* *}$ \\
Access to Conventional Information Source $\left(\mathrm{X}_{15}\right)$ & 0.175 & $0.003^{* *}$ \\
\hline Coefficient of Pathway $\mathrm{X}_{2}$ to $\mathrm{Y}_{1}$ & 0.273 & $0.000^{* *}$ \\
\hline
\end{tabular}

$* *$ Significantly different at the level of 0.01

* Significantly different at the level of 0.05

X1:Characteristics of Progressive Farmers, X2: Social capital of Community

Y1: Capacity of Progressive Farmers

Determination (R Square) of variables and sub-variables affects the capacity of progressive farmersapproximately of 60 percent, whilethe 40 percent were affected by other factors that not found in this study (Table 5). The analysis results also show that Model $\mathrm{Y}_{1}=0.249 \mathrm{X}_{11}+0.080 \mathrm{X}_{12}+$ $0.201 \mathrm{X}_{14}+0.175 \mathrm{X}_{15}+0.086 \mathrm{X}_{2}+\varepsilon_{1}$ is significant. Characteristics of progressive farmers including age, formal education, access to information technology, access of conventional information source and social capital of community directly affect the capacity of progressive farmers positively. These results indicate that progressive farmers as members of the social system have an orientation to always develop their capabilities and willing to have an open attitude towards the changes that occur so they will easily interact with the environment because they are able to access various information. This is confirmed by Rogers and Shoemaker (1971) who states that an individual of a social system who has progress-oriented mindset will always be willing to change, open to new experiences, and diligently searching for information.

The results of interviews with progressive farmersconfirmedthat factors that have a high enough effect in building their capacity is the ease of access to obtain information technology currently. The presence of advanced technology and information helpsprogressive farmersto choose a variety of alternative sources of information needed both from electronic media such as radio, television and print media such as newspapers, magazines, brochures, and others. Another alternative is through the internet. The internet is one of the most sophisticated ways to obtain information, as it can reach globally and quickly accessed by local agricultural development actors simultaneously (Mulyandari and Ananto 2005). Nevertheless, efforts to building the capacity of progressive farmers through non-formal education which implemented by education institutions and government extension services are still needed, although it is currently not optimal. In addition, progressive farmers need government supports in building and improving their capacityin term of extension methodology in order to be reliable in empowering the farmers, thus the interdependence of farmers can be achieved because they have a companion who has a high capacity and understand the needs and problems faced by farmers.

Capacity building of progressive farmers is one of the real efforts so that the progressive farmers can be involved more intensively in extension implementation because nationally the number of progressive farmers in the agricultural sector is currently quite large. If progressive farmers are given the opportunity, involved and supported optimally, they may accelerate the development of rural agriculture.Therefore, the presence of progressive farmers may provide an alternative solution for extension workforce which has been a difficult problem to be solved because of the moratorium on the appointment of extension agents by the government. In addition, progressive farmers work voluntarily and understand the conditions of farmers better. The use of paradigm of participatory extension and removal of government's old pattern (top-down) 
can be realized if progressive farmers have good capacity in performing their role as the agent of change so that the acceleration of rural development can be achieved well. Hence, capacity building of progressive farmers is important to be performed by the government so that they have the ability to organize and establish the farmers.

\section{Factors Affecting the Interdependence of Progressive Farmers}

Interdependence of progressive farmers is directly influencedby formal education factors, access to information technology, social capital, and capacity of the community, while it is indirectly influenced by age, non-formal education, and access to conventional information sources (Figure 1).Determination (R Square) of variables and subvariables which influenced the interdependence of progressive farmers contributesapproximately of 68.3 percent, while approximately of 31.7 percent influenced by other factors which are not present in this study (Table 6). The analysis results also show that $\mathrm{Y}_{2}=0.021 \mathrm{X}_{12}+0.026 \mathrm{X}_{14}+0.385 \mathrm{X}_{2}+0.589 \mathrm{Y}_{1}+\varepsilon_{2}$ is significant. This means that in order todevelop the interdependence of progressive farmers, it is required the support of the social capital and the capacity from the community which are reflected through formal and non-formal education and its access to information sources.

These results confirm the research of Abas (2016) that increased knowledge of the educational process is directly related to the levels of interdependence. The higher the level of education, it may lead a progressive farmer to be an independent thinker and able to make the right decisions. Ruhimat (2014) also states that independence is influenced by managerial skills, social skills and dynamism levels (innovative creativity, and competitiveness).

Access to high information technology owned by progressive farmers also encourages the level of interdependence they have, because they are able to be independent from dependence on government extension agents so that innovations and new information relevant to farmers can be obtained through other sources. Progressive farmers who gain information and utilize technology will be more dynamic in carrying out their assistance and learning to farmers, thus progressive farmers will perform the extension activities through the information. This is in line with Idoma and Muhammad (2013)and Utami and Sumardjo (2006) that innovation affects business independence, because innovation is one factor that must be owned by individuals to support socio-economic interdependence and development.

Table 6 Statistical analysis of factors affecting the interdependence of progressive farmers

\begin{tabular}{lcr}
\hline \multicolumn{1}{c}{ Variable } & Value & p-value \\
\hline R square & 0.683 & \\
\hline Coefficient of pathway $\mathrm{X}_{1}$ to $\mathrm{X}_{2}$ & & \\
Age $\left(\mathrm{X}_{11}\right)$ & 0.008 & 0.849 \\
FormalEducation $\left(\mathrm{X}_{12}\right)$ & 0.021 & $0.026^{*}$ \\
Non-Formal Education $\left(\mathrm{X}_{13}\right)$ & 0.047 & 0.242 \\
Access to Information Technology $\left(\mathrm{X}_{14}\right)$ & 0.026 & $0.050^{*}$ \\
Access to Conventional Information Sources $\left(\mathrm{X}_{15}\right)$ & 0.046 & 0.257 \\
\hline Coefficient of pathway $\mathrm{X}_{2}$ to $\mathrm{Y}_{2}$ & 0.085 & $0.020^{*}$ \\
\hline Coefficient of pathway $\mathrm{Y}_{1}$ to $\mathrm{Y}_{2}$ & 0.589 & $0.005^{* *}$ \\
\hline
\end{tabular}

$* *$ Significantly different at the level of $0.01, *$ Significantly different at the level of 0.05

$\mathrm{X}_{1}$ : Characteristic of progressive farmers, $\mathrm{X}_{2}$ : Social capital of community

$\mathrm{Y}_{1}$ : Capacity of progressive farmers, $\mathrm{Y}_{2}$ : Interdependence of progressive farmer

For progressive farmers, the social capital of the community is one of the factors that can encourage their interdependence. This is because progressive farmers can be trusted to make changes to their communities, safeguard the existing values of the rural areas and build cooperation with other stakeholders. This is in accordance with the statement of Arianto and Fitriana(2013) that the existence of social capital of community can be a cover of social bond that encourages the presence of interdependence with the government and other sectors. A detail of direct and indirect influence of each variable on the interdependence of progressive farmers is illustrated as in Figure 1. 


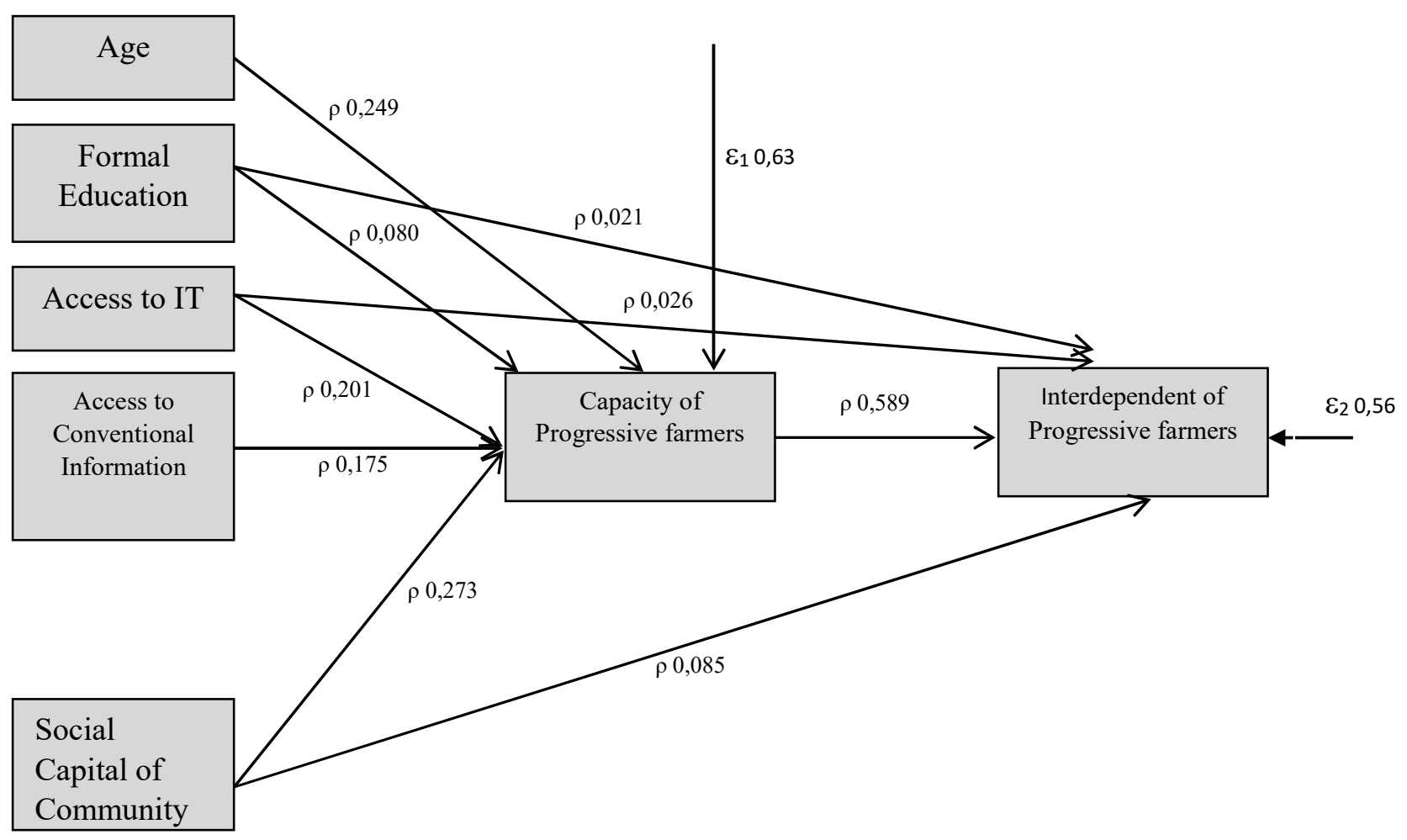

Figure 1 . The results of pathway analysis affecting interdependent of progressive farmers

Based on this study, interdependence is interpreted as a form of the ability of progressive farmers as agents of change in rural areas in utilizing the potential of themselves and their external environment to be better which is characterized by freedom in determining the best choices for their life.One way that can be done to exploit such potential is to maximize the capacity owned so that such potential can be improved, as well as determine the best decisions in their lives which supported by external environment in the form of social capital of the community.

The result of the path analysis shows that the effect of the capacity of progressive farmers contributes significantly to the interdependence level of progressive farmers, followed sequentially by social capital, age, access to information technology, access to conventional information sources, and formal education level (Table 7).

Table 7. Effect of each variable on the interpendence of progressive farmers

\begin{tabular}{lrrr}
\hline \multicolumn{1}{c}{ Variable } & \multicolumn{1}{c}{ Direct Effect } & $\begin{array}{c}\text { Indirect Effect } \\
\text { Through the Capacity }\end{array}$ & \multicolumn{1}{c}{ Total Effect } \\
\hline Age & - & 0.146 & 0.146 \\
Formal Education & 0.021 & 0.047 & 0.068 \\
Non-Formal Education & 0.026 & 0.118 & 0.144 \\
Access to Conventional & - & 0.103 & 0.103 \\
Information Sources & 0.085 & 0.160 & 0.245 \\
Social Capital of Community & 0.589 & - & 0.589 \\
Capacity of Progressive & & & - \\
Farmers & & &
\end{tabular}

This means that the capacity of progressive farmers plays a major role in encouraging themselves to be interdependent individuals that are capable of performing their role as agents of change in rural areas with the encouragement of social capital from the community and the presence of access to information technology. These results confirm the research of Sumardjo (1999) that another feature of a true interdependent individual is having advanced, efficient, highly competitive behaviors 
(cognitive, affective and psychomotor), to think or act quickly and accurately, as well as be able to partner and build a network which is mutually reinforcing.

In contrast to the internal characteristics of progressive farmers, these factors may increase their interdependence if there is an adequate capacity building of progressive farmers by strengthening access to information resources and various training activities (non-formal education). It strengthens the result obtained by Haryanto and Yuniarti (2017)that capacity building is a requirement needed by progressive farmers to play their roles well in order to have a good farming, have a good quality of life, and have products with a high competitiveness with other stakeholders. Inorderto realize those expectations above, it is needed the attention of the government to optimize the role of educational institutions and training activities in improving the capacity of progressive farmers. This is in line with Utami and Sumardjo (2006); Idoma and Muhammad (2013)and Alonge et al. (2014) that the role of government is still needed to improve the independence of common farmers and progressive farmers, particularly through non-formal education so as to become a quality and innovativeperson.

According to deductive study of Covey (2013) on the continuum of the behavioral maturity, Sumardjo(2012) on the interdependence of progressive farmer, as well as some previous studiesSumardjo (1999); Utami and Sumardjo (2006); Marliati et al. (2008), it isconfirmedthat development of the interdependence of progressive farmers can be realized through capacity building so as to optimize their role as agent of change in rural areas. Interdependence of progressive farmers is the resultof the increase in the capacity and potentials of progressive farmers so that their role can be optimum in empowering, organizing and managing farmer to farmer extension independently which accompanied by the other environmental supports.

\section{CONCLUSIONS}

Progressive farmers have good capacity in empowering farmers. It demonstrates that the capabilitiesowned by progressive farmers in terms oftechnical assistance, disseminating innovations that are appropriate to the needs of farmers, providing farmer to farmer extension, being informal leaders, and maintaining local wisdom can be the basic capitals for progressive farmers as agents of change in rural areas.Progressive farmers also have a high level of independence. This indicates that progressive farmers have the initiative and the willingness to realize their expectation (competitiveness), are able to cooperate in partnerships and have a high filter system in determining the best decision for farmers' empowerment activities.Factors supporting the capacity building of progressive farmers are age, formal education, access to information technology, access to conventional information sources and social capital of the community. The capacity of progressive farmers contributes significantly to the interdependence of the progressive farmers, followed sequentially by age, access to information technology, access to conventional information sources.

\section{REFERENCES}

Abas, M. S. (2016). Factors influencing self-reliance in rice production, the case of small farmers in Bataan, Philippines. International Journal of Agricultural Technology, 12(1), 41-53.

Aker, J. C. (2011). Dial "A" for agriculture: A review of information and communication technologies for agricultural extension in developing countries. Agricultural Economics, 42(6), 631-647. https://doi.org/10.1111/j.1574-0862.2011.00545.x

Alonge, H. O., IGE, A. M., \& Osagiobare, O. E. (2014). Women Empowerment For Self-Reliance: Educational Management Strategies in Nigeria Case. Journal of Educational and Social Research, 4(1), 517-524. https://doi.org/10.5901/jesr.2014.v4n1p517

Brown, K., \& Westaway, E. (2011). Agency, Capacity, and Resilience to Environmental Change: Lessons from Human Development, Well-Being, and Disasters. Annual Review of Environment and Resources, 36(1), 321-342. https://doi.org/10.1146/annurev-environ-052610-092905

Burton, R. J. F. (2014). The influence of farmer demographic characteristics on environmental behaviour: A review. Journal of Environmental Management, 135, 19-26. https://doi.org/10.1016/j.jenvman.2013.12.005

Emery, S. B. (2014). Independence and individualism: conflated values in farmer cooperation? Agriculture and Human Values, 32(1), 47-61. https://doi.org/10.1007/s10460-014-9520-8 
Emery, S. B., \& Franks, J. R. (2012). The potential for collaborative agri-environment schemes in England: Can a well-designed collaborative approach address farmers' concerns with current schemes? Journal of Rural Studies, 28(3), 218-231. https://doi.org/10.1016/j.jrurstud.2012.02.004

EN, A. K. dan F. (2013). Modal Sosial dalam Kemandirian Masyarakat di Bidang Kesehatan. Kebijakan Dan Administrasi Publik, 17(2), 37-49.

Haryanto, Y., \& Yuniarti, W. (2017). The Role of Farmer to Farmer Extension for Rice Farmer Independence in Bogor. International Journal of Research in Social Sciences, 7(4), 62-74.

Idoma, K., \& Muhammad, I. (2013). Self-Reliance: Key to Sustainable Rural Development in Nigeria. ARPN Journal of Science and Technology, 3(6), 585-592.

Indraningsih, K. S., Sugihen, B., Tjitrpranoto, P., Asngari, P., \& Wijayanto, H. (2016). Kinerja Penyuluh dari Perspektif Petani dan Eksistensi Penyuluh Swadaya Sebagai Pendamping Penyuluh Pertanian. Analisis Kebijakan Pertanian, 8(4), 303-321. https://doi.org/10.21082/akp.v8n4.2010.303-321

Jatnika, A. (2016). No Title.

Kiptot, E., \& Franzel, S. (2014). Voluntarism as an investment in human, social and financial capital: Evidence from a farmer-to-farmer extension program in Kenya. Agriculture and Human Values, 31(2), 231-243. https://doi.org/10.1007/s10460-013-9463-5

Läpple, D., Hennessy, T., \& Newman, C. (2013). Quantifying the economic return to participatory extension programmes in Ireland: An endogenous switching regression analysis. Journal of Agricultural Economics, 64(2), 467-482. https://doi.org/10.1111/1477-9552.12000

Lukuyu, B. (2012). The Journal of Agricultural Education Disseminating Improved Practices : Are Volunteer Farmer Trainers Effective? Disseminating Improved Practices: Are Volunteer Farmer Trainers Effective? (October), 37-41.

Marliati, M., Sumardjo, S., Asngari, P. S., Tjitropranoto, P., \& Saefuddin, A. (2008). FAKTORFAKTOR PENENTU PENINGKATAN KINERJA PENYULUH PERTANIAN DALAM MEMBERDAYAKAN PETANI (Kasus di Kabupaten Kampar Provinsi Riau). Jurnal Penyuluhan, 4(2). https://doi.org/10.25015/penyuluhan.v4i2.2174

Mulyandari, Retno \& Ananto, E. (2005). Sumber Informasi Pertanian Nasional. Informatika Pertanian, 14(1), 802-817.

Niska, M., Vesala, H. T., \& Vesala, K. M. (2012). Peasantry and Entrepreneurship As Frames for Farming: Reflections on Farmers' Values and Agricultural Policy Discourses. Sociologia Ruralis, 52(4), 453-469. https://doi.org/10.1111/j.1467-9523.2012.00572.x

Oktavia, Y., Muljono, P., Amanah, S., \& Hubeis, M. (2017). Jurnal Penyuluhan, September 2017 Vol. 13 No. 2 Hubungan Perilaku Komunikasi dan Pengembangan Kapasitas Pelaku Agribisnis Perikanan Air Tawar di Padang, Sumatera Barat. Jurnal Penyuluhan, 13(2), 157-165.

Omorede, C. K. (2014). Organising Rural Women for Socio-Economic Development and SelfReliance in Nigeria: Challenges and Prospects. Business and Management Research, 3(2), 4759. https://doi.org/10.5430/bmr.v3n2p47

Riana, Satria, A., \& Purnaningsih, N. (2015). The Role of Self-Support Extension Agents in Supporting Intensification Cocoa in Sigi District Central Sulawesi. Jurnal Penyuluhan, 11(2), 201-211.

S., H., Sumardjo, S., Asngari, P. S., Tjitropranoto, P., \& Susanto, D. (2008). Kapasitas Petani Dalam Mewujudkan Keberhasilan Usaha Pertanian: Kasus Petani Sayuran Di Kabupaten Pasuruan Dan Kabupaten Malang Provinsi Jawa Timur. Jurnal Penyuluhan, 4(1). https://doi.org/10.25015/penyuluhan.v4i1.2164

Saepudin Ruhimat, I. (2014). Faktor-Faktor Untuk Peningkatan Kemandirian Petani Dalam Pengelolaan Hutan Rakyat: Studi Kasus Di Desa Ranggang, Kabupaten Tanah Laut, Kalimantan Selatan. Jurnal Penelitian Sosial Dan Ekonomi Kehutanan, 11(3), 237-249. 
https://doi.org/10.20886/jsek.2014.11.3.237-249

Selener D, J Chenier, R. Z. (1997). Farmer to Farmer Extension lessons from the field. New York: IIRR.

Shelton, D. P., Wilke, R. A., Franti, T. G., \& Josiah, S. J. (2009). Farmlink: Promoting conservation buffers farmer-to-farmer. Agroforestry Systems, 75(1), 83-89. https://doi.org/10.1007/s10457008-9130-9

Sumardjo. (1999). Transformasi model penyuluhan pertanian menuju pengembangan kemandirian petani (Kasus di Propinsi Jawa Barat) [disertasi]. 1-372.

Sutherland, L. A., Burton, R. J. F., Ingram, J., Blackstock, K., Slee, B., \& Gotts, N. (2012). Triggering change: Towards a conceptualisation of major change processes in farm decision-making. Journal of Environmental Management, 104, 142-151. https://doi.org/10.1016/j.jenvman.2012.03.013

Syahyuti, N. (2016). Peran Strategis Penyuluh Swadaya dalam Paradigma Baru Penyuluhan Pertanian Indonesia. Forum Penelitian Agro Ekonomi, 32. https://doi.org/10.21082/fae.v32n1.2014.43-58

Utami HN, Sumardjo. 2006. Faktor-Faktor yang Berhubungan dengan Kemandirian Pengrajin Kulit di Kabupaten Sidoarjo dan Magetan, JawaTimur. Jurnal Penyuluhan. 2(4): 42-50.

Verhagen K. 1996. Pengembangan Keswadayaan: Pengalaman LSM di Tiga Negara. Terjemahan. Jakarta (ID): PuspaSwara.

Yunita. 2011. Strategi Peningkatan Kapasitas Rumah Tangga Petani Padi Sawah Lebak Menuju Ketahanan Pangan Rumah Tangga (Kasus di Kabupaten Ogan Ilir dan Ogan Komering Ilir, Sumatera Selatan) [Disertasi]. Program Pascasarjana, Institut Pertanian Bogor. 